\title{
Affected Men: Agency, Masculinity and the Race Episteme in Caryl Phillips's Dancing in the Dark and Foreigners
}

\section{Eva Ulrike Pirker}

\section{(2) OpenEdition}

\section{Journals}

Electronic version

URL: https://journals.openedition.org/ces/4514

DOI: $10.4000 /$ ces.4514

ISSN: 2534-6695

Publisher

SEPC (Société d'études des pays du Commonwealth)

\section{Printed version}

Date of publication: 1 September 2017

Number of pages: 117-133

ISSN: 2270-0633

\section{Electronic reference}

Eva Ulrike Pirker, "Affected Men: Agency, Masculinity and the Race Episteme in Caryl Phillips's Dancing in the Dark and Foreigners", Commonwealth Essays and Studies [Online], 40.1 | 2017, Online since 02 April 2021, connection on 27 January 2022. URL: http://journals.openedition.org/ces/4514 ; DOI: https://doi.org/10.4000/ces.4514

\section{(c) (i) $\odot$}

Commonwealth Essays and Studies is licensed under a Licence Creative Commons Attribution - Pas d'Utilisation Commerciale - Pas de Modification 4.0 International. 


\section{Affected Men: Agency, Masculinity and the Race Episteme in Caryl Phillips's Dancing in the Dark and Foreigners}

This article explores Caryl Phillips's approaches to narration and characterisation with a specific focus on the "troubled masculinites" he projects in his literary biographies

Dancing in the Dark and Foreigners. His male protagonists' individual striving towards independent, self-governed, successful, or simply dignified lives habitually clashes with the societal ascriptions they experience, and especially with the constraints imposed by a powerful player in their lives: the race episteme.

Caryl Phillips has been noted for his construction of complex female voices and experiences (Pulitano 375). Yet, in most of his works, these are juxtaposed with equally challenging male experiences and perspectives, and in some, Phillips has foregrounded his focus on "troubled" masculinities, or more specifically, the limitations of black male agency in Western contexts. This article examines Phillips's literary constructions of black men and their developments with a particular interest in his negotiation of concepts of achievement and failure. It focuses on two works which can be categorised as literary biographies, Dancing in the Dark (2004) and Foreigners (2007). The former centres on the life of vaudeville performer and entertainer Bert Williams (1874-1922) in the United States. The latter assembles the otherwise unconnected biographies of three black men in England: Francis Barber (c. 1742/3-1801), the servant and protégé of the lexicographer Dr. Samuel Johnson; the boxer and short-time world champion Randolph Turpin (1928-1966); and David Oluwale (1930-1969), a Nigerian migrant and victim of police violence in Leeds. None of their stories lends itself to a straightforwardly revisionist or even celebratory approach, but Phillips's choice to cast them as radical downward spirals of disappointment and doom raises questions concerning his agenda in his portrayals of black men's lives across the last two or three centuries.

In all his literary biographies, Phillips addresses concepts of achievement that have permeated Europe and the New World from the Enlightenment onwards. The notion of the free individual whose right (or unwritten moral obligation) to pursue happiness is even constitutionally fixed in the United States has held an inestimable appeal across the world. ${ }^{1}$ Yet, the question of wherein achievement resides and how it might be measured is not determined by striving individuals alone, but by the social contexts in which they move. And, as Phillips's biographies remind us, the unwritten rules of eligibility into the circle of those who qualify to become free and achieving individuals are determined by such intersecting parameters as race, class and gender and the respective societal ascriptions. The fact that Dancing in the Dark and Foreigners were written consecutively, preceded and followed by works which equally engage with the marred developments of black male individuals ${ }^{2}$ suggests that this matter preoccupied Phillips centrally throughout the

1. Linked to material prosperity and social status in the seventeenth and eighteenth centuries the term "happiness" became normatively charged in the course of the nineteenth century, denoting a "healthy" state, a fulfilment of norms. ("Happiness") The internalisation of Western notions of happiness and achievement across the globe, which is partly a legacy of European colonialism, was already harshly criticised by Frantz Fanon (312).

2. Male characters who fail to live up to their own or others' expectations appear across Phillips's oeuvre, but his interest in them seems to have become more focused after the 1990s: The Atlantic Sound (2000) juxtaposes a deported 
first postmillennial decade, a decade during which it had otherwise become fashionable to proclaim a "post-racial," "post-black," and "post-feminist" era on both sides of the Atlantic (cf. Hollinger). Phillips's explorations of the racialised and patriarchal aspects of present-day concepts of achievement and structures of domination, as in the novel In the Falling Snow (2009), are a direct challenge to the "we're beyond race" or "race doesn't matter" discourses of recent years (Markus and Moya 6-7). His prolonged creative engagement with historical lives, however, exposes the longevity of the "race-episteme" in Western contexts, i.e. the fixation of black individuals - and especially men - in whitedominated societies as either requiring control and correction or guidance and help. In either case, it denies black men maturity, responsibility and agency, and this denial appears especially dramatic when perceived against the backdrop of Western post-enlightened discourses in which aspiring men were increasingly measured in terms of their ability to perform as "pursuers of happiness." Variations of the race-episteme and its effects on individuals are projected in all four biographies of Dancing in the Dark and Foreigners.

In Philips's oeuvre, narrative genres dominate. With their traditional reliance on sequenciality and causality, narratives typically lend themselves to explorations of formation and development, and this feature appears especially evident in the genre of life writing and biography. Importantly, however, biographical writing can also be said to be driven by a revisionist impetus. The four men portrayed in Dancing and Foreigners are typically seen as neglected by historiography, and Phillips's fictionalisation of their lives is understood as restorative effort (cf. e.g. Birat 47-8). In all four cases, however, there is evidence to the contrary, and Phillips's artistic choices - the choice to deviate from available narratives, the choice not to give prominent space to "authoritative" perspectives that might have changed the impression of the portrayed lives, and hence the choice of a stark portrayal of the four men's downfall - deserve to be accounted for. Phillips does contribute to putting the four men back on the agenda, and more: by showing them as affected by their respective social environment he seems to invite us to an empathetic attitude. Through his narrative strategies, however, he consistently denies us the illusion of an immediate, empathetic indulgence or even identification. All the same, we are made to perceive the structural injustices affecting them acutely. In my reading, I will explore Phillips's approach to, and interpretation of, the lives of the four individuals, an interpretation which brings a powerful hidden player in their lives, the race episteme, to the surface.

\section{The performer}

Vaudeville performer Bert Williams gained international fame as perhaps the "first black [...] popstar" of his days (Chude-Sokei 1; Forbes). Williams's fame was generated by his highly skilled impersonation, in blackface, of a slow-witted clown - a role which reinforced the white stereotype of "how the Negro is viewed in America" (Phillips, Dancing 179). Phillips's text Dancing in the Dark casts Williams as a struggling man intent on maintaining the illusion that he is acting with as much freedom and dignity as the circumstances permit, yet increasingly aware of the sacrifice these circumstances demand.

Ghanaian ex-student and the late nineteenth-century John Emmanuel Ocansey, who both fail to realise their plans. The protagonist of In the Falling Snow (2010) has to come to terms with his failed marriage and professional life, both of which are complicated by racialised social settings. 
Although an "ambitious man" who is "married to [his] work" (39), he is only allowed the gratification of achievement within the carefully policed constraints of his (white) audience's expectations. "That he has to "play the role America has set aside for him" becomes clear to Phillips's Williams at a young age, soon after his family has migrated to the United States from the Bahamas. His parents, who harbored dreams of "remak[ing] themselves in the new American world" discover at their first port of call, Florida, that "in this new place they are simply Negroes" $(23,24)$. Rather than accept the defeat and return, they try their luck in California, where Williams finishes school. However, realising his vocation as a performer, he decides against training in a more conventional field - "for to perform [...], but to receive neither laughter nor applause in return seemed to him to defeat the whole purpose of the exercise" (25-6), and the first engagements he secures are as jostler for touring medicine shows.

Whereas Camille Forbes describes the medicine show as instructive training ground for the teenager who "had quit school to follow his dream" (17), Jessie Fauset's obituary article in The Crisis of 1922 draws attention to the limitations which she thought played their part in Williams's choices, from his time

as a boy in the High School in California [...]. His first glance at those limitations revealed that he could not afford to attend Leland Stanford University as he had dreamed; his second revealed that though he had a decided liking for the stage and even a slight possibility of gratifying his liking, color would probably keep him from ever making "the legitimate." (Fauset 13)

"Subjectively," Fauset continues, "his power was limitless; objectively it had to soar up but not outwards" (ibid.). Phillips's portrayal tends towards Fauset's. When his Williams meets Kansas-born George Walker in San Francisco, the two young men move "in and out of the city's saloons and variety halls, where they learn to obliterate their true selves" as minstrel boys; they pose as "real Africans" in the Dahomeyan village of the 1894 Golden Gate exposition; eventually, they tour the stages and backrooms of young mining towns as duo, with Williams "as the straight man and George as the comedic banjo picker." Yet, they grow "weary of trying to be something other than the colored monkeys that the audience" expects (31) and increasingly conscious of "the true extent of the danger" they find themselves in when they are made to leave a town stripped of their clothes at gunpoint after a performance. Turning their backs on the stage is out of the question. They realise, however, that "they have to try something new" to make their performance more successful, which leads to their fateful decision, in 1896 in Detroit, to "exchange roles" with Walker becoming "the straight, dandified character" and Williams "the lazy, slow-footed [...] Negro" who, on top of this, adopts "cork" (30-1, 33-36).

3. That Williams was also appreciated by black audiences (Sotiropoulos 6) is not stressed in Phillips's text, which puts the limitations imposed on black artists and Williams's "tightrope" act between "his needs and his audience's expectations" (Phillips, Dancing 191) in sharp focus, with the audience emerging effectively as the sole factor in the game. The historical Williams said about his limitations: "On the stage we judge the success of a piece by the applause and by the box-office receipts. The newspapers often give us a hint of the public's mind," but adds that he would prefer to show "both sides" (B. 21).

4. In his essay "The Comic Side of Trouble" Williams describes the choice as somewhat accidental: "[O]ne day at Moore's Wonderland in Detroit, just for a lark I blacked my face [...]. Nobody was more surprised than I when it went like a house on fire. Then I began to find myself" (Williams 34, 60). In Phillips's text, Williams is said to have "erased" and "wiped himself clean of the face of the earth" when putting on the mask (Dancing 58). Forbes describes the cork as "the buffer between the audience and the inner Williams [...], now protected [...] from having to be the persona he portrayed on the stage" (48). 
The "two real coons" bring Walker and Williams to New York, where they open their own Browadway show In Dahomey. Although Walker's unease with what they stand for increases proportionally to his growing political consciousness, the two continue as a team and even travel to England, where a performance in front of the king becomes a highlight in Williams's career. After Walker's untimely death Williams joins the famous Ziegfeld Follies as the first black entertainer and eventually founds his own show. He is, however, unable to free himself from either the role of the clown or the mask. The slightest attempt at doing so is greeted with disapproval from his white audience. The judgement of that audience weighs more than that of his father or the representatives of the black political intelligentsia, of whose disapproval Phillips's Williams is shamefully aware throughout his stage life: "the trauma of having to look up to the upper balcony" where the "colored" audience is seated in segregated America, "takes its toll" (29), ${ }^{6}$ and when Williams's father eventually attends a performance, Williams "cannot bring himself to look up" (84). Yet, why does he continue? Although he is financially secure, retirement is impossible for Williams, for whom any stage appearance is preferable to no stage appearance. To imitate and perfectly perform is his vocation from his childhood onwards, when "he would sit patiently [...] and study the manner in which chickens threw dust behind them" (83). His character dies when he collapses on stage in Detroit - Williams dies a few days later in New York.

Phillips takes notable artistic liberties in his literary biography. Especially striking is his unambiguous portrayal of Williams's father as bewildered by his son's performance. Frederick Williams is elsewhere quoted as having said that he punished his son "at first" for developing his talent "while only a child [...] but soon discovered that punishment was of no use. I am mighty glad now, that that spark was there and that it developed in spite of us older folk" (Chude-Sokei 55; also Forbes 21). Both father and son are reported as having been proud of their family's elevated status in the Bahamas. In contrast to his partner George Walker, Williams was "light-skinned enough to appear white" (Forbes 17), and his own dealing with his mixed-race identity and the different implications this had in the Caribbean and in the United States must have been fraught with ambiguity, and may partly account for his not taking sides more vociferously in black political matters. The recorded occasions on which he expressed regret at the way black men were treated in the United States appear like understatements: "I have never been able to discover that there was anything disgraceful in being a colored man. But I have found it inconvenient - in America" (Williams 34). Williams is widely perceived as having been limited by a racist culture. His alleged complicity in perpetuating this culture $^{7}$ at a time when it was beginning to be challenged loudly accounts for the relative silence surrounding his achievements during the second half of the twentieth century, which is staged in the "Prologue" of Dancing in the Dark: already here, Phillips's text forces his readers to leave the comfort zone maintained by suppressing and warding off the memory of Williams's performance. In the novel's opening sentence, "If you walk

5. Walker and Williams advertised themselves thus in response to white performers in blackface and with an emphasis on "real." Rather than displaying a complicitness with a racist stereotype, the label can be read as reflecting the irony of black men parading, and hence to some extent subverting, a stereotypical role. This irony, of course, was lost on a substantial section of their audience.

6. The term "Nigger Heaven" is repeatedly used in the novel, bringing readers face to face with the cultural violence of racial discrimination.

7. David Krasner lists a number of contemporary examples of praise and condemnation (269-70). 
Agency, Masculinity and the Race Episteme in Caryl Phillips's Dancing in the Dark and Foreigners

down Seventh Avenue today he is a man who never existed" (3-4), we are paradoxically made aware of the present ("today") gaping absence of "a man who never existed," and the use of the second person draws us into the narrator's experience of that absence. The next paragraph is set off and draws our attention to the past: "In his time [...]" (4, emphasis in the original), twice repeated, prepares us for a change to the irrevocably different social setting of Harlem a century earlier. The dramatisation of an absolute difference between the settings, the gap between the paragraphs and the emphasis of temporal markers highlights the silence surrounding Williams for many years and the challenges in approaching him.

Some contemporary and recent reappraisals attempting to rescue Williams from oblivion have drawn attention to the subversive approaches, double consciousness (Fauset) ${ }^{8}$ and "plural masking" (Chude-Sokei 53) evident in his art. In their efforts to show Williams as a man with agency, they emphasise his professionalism and habitually reference the few recorded occasions on which he has spoken or written about himself offstage. That the historical Williams worked assiduously to perfect his skills is beyond doubt. The fact that he amplifies his professionalism shows that it was a significant aspect of his self-conception: Williams mentions his habit of making "the round of the theatres on Sundays" with the purpose of seeing "how the other fellows work" and his regular studies with "Pietro, the great pantomimist" in Europe (B. 22; Williams 106). None of the researchers engaging with Williams to date have verified the Pietro-story, and several reappraisals of Williams integrate it without interrogation, displaying a collective desire to read the few instances of an underrepresented, first-hand account as imbued with truth, note- and quoteworthy and effectively creating a spiral of authentification. A notable exception is Camille Forbes, who sheds light on mutually contradicting accounts by Walker and Williams, thus drawing attention to the autopoetia inherent in Williams's accounts of himself, and who omits the Pietro story altogether. By doing so, however, she omits an integral aspect of Williams's self-fashioning, which sits squarely among the few available source materials.

Phillips's artistic approach to the Pietro story is different: In Dancing, it is repeated in a direct quotation from Williams's text, but framed by fictional passages, which give insights into the thought-world of the dying, raving Walker and cast doubt on Williams's version: "[B]ut George suspects that, in his mind, Bert travels. [...] But George knows that Bert travels only in his mind" (141). Whereas Walker's delirious consciousness can be questioned, a second voice of a reporting journalist confirms the moment of doubt, and may well reflect Phillips's own situation when researching Williams's life:

[A]lthough I read everything that I could find, I found it impossible to discover anything about this Mr. Pietro. [...] [N]obody I questioned had any memory of Mr. Williams ever doing any studying in Europe. When [...] sitting opposite Mr. Williams I had second thoughts about raising this puzzling quandary. (142)

Just as Walker's mind is inaccessible, and his moment of doubt hidden on the diegetic level, the reporter's doubts remain in his thoughts, unrevealed to his readers and to

8. Forbes examines black performers' (including Williams and Walker's) practice of appealing to both sides of their segregated audience, the "black audiences read[ing] against the grain" (39). Although the performers "knew their success depended on the satisfaction of an overwhelmingly white audience, their songs turned attention to the black audience" (102). Striving "to remain loyal to their black audience without alienating the white audience, and to entertain the white audience without degrading themselves and their black audience" (115, 120-1), however, also presented a "growing dilemma" (163-72). 
Williams. On the extradiegetic level, however, these doubts are exposed to Phillips's readers. By casting doubt on the Pietro-story, which authoritatively emphasises Williams's professional attitude both for himself and in narratives about him, Phillips's text exposes not only attempts at (re-)mythologising Bert Williams, but also Williams's own part in the creation of his autobiographical myth. It shows that Williams was not only limited by the racialised structures of his environment, but also caught in a plot in which he had to perform as an overachiever in his craft. ${ }^{9}$ His professionalism is the most powerful argument in his - seemingly unobtrusive - charge against the limitations of the racist system he inhabited. Thus this professionalism becomes the vital aspect of his own story, the myth about himself. To cultivate and protect this myth, Williams formed his account of himself accordingly.

Casting doubt on some aspects of Williams's autobiographical utterances neither diminishes his artistic achievement nor the limitations he experienced, but renders him more human and his struggle more representative. The (auto-)descriptions of Williams's professionalism and his dependency on his audience's reactions show that one's sense of achievement is never intrinsic, but dependent on acknowledgement by others. By attempting to achieve, we both control norms and subject ourselves to them (Butler), and by doing so, we automatically affirm and perpetuate these norms. In his own process of subjection, Williams makes use of a powerful and exclusive tool that grants him an agency to which Walker and other black colleagues have no access: the mask. Williams can take off the mask and be - as he repeatedly emphasises - absolutely different. ${ }^{10}$ That this entails, in his case, the possibility of racial passing is something he does not specify. The mask, in this sense, is an instrument of control and agency used at the expense of all black men in the Western world who are subject to racialised ascriptions that mark them as inferior. The notion of control, however, is deceptive, as Williams has become dependent on an audience that is not interested in the man beneath the cork (Birat 53).

The man beneath the cork is interpreted in much detail by Phillips. If Phillips's portrayal of Williams's father is informed by an agenda external to Williams's context, then this agenda appears even more imposing in his portrayal of the artist's family life. Drawing from an interview with one of Lottie Williams's - Williams's wife - three orphaned nieces who used to live with the couple, Lloyd Lewis's posthumous article relates anecdotes which testify that Williams's wit and humour were by no means restricted to the masked character and the stage. When read against Lewis's - endearing - portrayal of "Uncle Eggs," Phillips's text appears like an act of balancing accounts: Phillips's Williams decides against taking his wife's nieces in; the fact that Williams was not a "Ladies" man" is magnified into sexual impotence, and his relationship with his wife is marked by awkward silences; generally, Phillips renders Williams as withdrawn and antisocial, and casts the sadness famously attributed to him by Buster Keaton in

9. A fictional exchange between Ada Walker and Lottie Williams in Dancing in the Dark highlights the implications of this professionalism: “'Fact is they're already married to their work.' [...] [Lottie] already knows that her husband-tobe is an ambitious man, and she has already discovered that $[\ldots]$ he has difficulty sharing his feelings" (39). Although convinced that he "possessed freedom in his work," he is shown as vulnerable, for instance when a young interviewer comments on "the colored actor Charles Gilpin" and Williams is unpleasantly reminded of the "implication of failure on his part, for he is most certainly not regarded as a colored actor. He is a colored performer. 'Actor' [...] suggests a certain dignity, and [...] a necessary distance between the performer and the character to be interpreted. This one word, 'actor,' if properly applied to him, might have spared his soul much misery, but he understands that nobody [...] considers him to be an actor" $(75,199)$.

10. The act of putting on and removing the cork is repeatedly described as intimate ritual. 
stark proportions. I read Phillips's striking distortion of facts - evident in his treatment of the nieces, who lived under Williams's roof until his death in 1922 (Lewis; Forbes 231), and in his portrayal of Williams not only as asexual, but sad and antisocial, although others have described him as someone who loved the company of debating men (Lewis 234) - as part and parcel of his interpretation of the artist as an individual controlled and dominated by his dependence on being seen as an achiever - and by his mask.

Phillips's portrayal of Williams brings his readers face to face not only with the racist environment which limits Williams's pursuit of happiness as a black male professional mime, but also with his voluntary subjection to the codes of that very environment, and with his eventual realisation that the mask controls him rather than vice versa. By structuring his biography of Williams like a dramatic piece in three acts - complete with pro- and epilogue and play-within-the-play scenes - Phillips literally sets the stage for Williams once more and makes his readers gaze at Williams's acts, but also at his gazing contemporary audience and at the emotional world of all affected by Williams's performance, including Williams himself. When confronted, in his own house, by "six finely dressed" representatives of the "Negro community" with the question "Why, $M r$. Williams, do you choose to play the shambling, pathetic dupe?' he replies:

I have to believe that my public is sophisticated enough to understand that I am impersonating a particular type who does not exist except in my imagination. Mr. Nail interrupted: And in their imagination, Mr. Williams. We exist in their imagination as you portray us, and you reinforce their low judgment of us as dull and pitiable. An exasperated Bert opened his arms wide. Am I responsible for the coarse imagination of some few among my audience? Am I responsible for how the Negro is viewed in America? (179, italics in the original $)^{11}$

Williams's insistence on the fictionality of his role, signalled by the mask and the stage, is suggested to be flawed. His (or the mask's) part in the "machineries of representation" (Hall) and in the cementing of (American) views is obstructive to advocates of a progressive politics, among them George and Ada Walker, who believe "that the day has come for the Negro to [...] stake his claim to a position of equality alongside his fellow white performers [...] and begin this process of moving away from the old darky stereotype." They plan to "change the situation [...]" and do away "with the limitations which other persons have made on us" $(118,119)$. Williams's ambivalent national and cultural affiliation ${ }^{12}$ allows him not only to distance himself from his role, but also from his African American colleagues. Part and parcel of this is his narrative of his European ties, of which the "Pietro" story becomes just as much a part as his performance in front of his English king. Importantly, Williams's positive experience of, and attitude towards, England does not make England a better place, but exposes Williams's internalisation of a colonial discourse in Fanonian terms. And even if erring readers of Dancing in the Dark have been lured into believing that continental Europe was somehow racially less charged than segregated America, Phillips sets the record straight once and for all

11. A few pages later, Phillips imagines Bert Williams watching himself uncorked in a preview show of the moving picture Darktown Jubilee with pride, "although he already understands that not everybody will share his feelings," and indeed, the audience outdoes itself in its violent reactions to "the uncorked colored person of cunning and resourcefulness" they were given instead of "the familiar "darky humor" they had expected (Dancing 191, 193). Darktown Jubilee is a lost short film about which little information is available (Forbes 369n86).

12. Williams was only naturalised in 1918 (Forbes 271). 
in Foreigners, in which the violent impact of racialised systems of codification on the development of three male protagonists in England is exposed.

\section{The servant}

Like the young Bert Williams a good century later, Francis Barber struggled against paternal expectations. Unlike Williams, he was unable to emancipate himself productively from these, although apparently "stubborn" and equipped with an "independent mind" (Debrunner 120). Barber's quasi-familial situation, of course, was very different from Williams's and unlike the latter's, it dominates the scarce accounts of Barber's life. In the first section of Phillips's Foreigners, “Dr. Johnson's Watch," events in Barber's life are related in analepses (23-33, 38-42). Born in Jamaica in the early 1740s, he is taken to England, educated and "given" to Dr Johnson, who treats him like a son rather than a servant. Johnson invests in a solid education and fosters hopes regarding the young man's success in the world of letters. Barber, however, refuses to be pressed into the template of Johnson's ideas, and once he reaches a rebellious age and acquires the status of a free man, he runs away twice, first to an apothecary, then to sea. Anxious that his protégé might be kidnapped back into slavery, Johnson arranges for his discharge from the navy, summons him home and sends him to grammar school. ${ }^{13}$ Barber returns to Johnson with an improved education, falls in love with, and marries, an English woman. His growing family keeps old and ailing Johnson company until the lexicographer dies - an incisive moment, which marks the end of Barber's integration in a supportive system. The money and items (e.g. the titular watch) inherited from Johnson are soon spent; ill-advised and betrayed, the family moves to Johnson's hometown Lichfield with plans to run a school, but the scheme fails, and Barber succumbs to drinking and eventually dies lonely and forgotten in a workhouse infirmary. Phillips's Barber, in fact, is thought dead before his actual demise, which underlines his state of isolation.

Barber's downfall, in Foreigners, appears especially stark through the contrast with the extensively described "sheltered" context provided by Johnson. His development within this context is cast in terms of that of a prototypical rebelling teenager, who is reluctant to learn $(31,35)$ and prone to running away, but eventually develops insights into Johnson's fatherly reasoning. Not only is Barber depicted as happy in the company of Johnson, Johnson's fondness for, and anxiety on behalf of, Barber are highlighted. An accumulation of such phrases as "Francis continued to feel happy in the company of this kind, if somewhat eccentric, man" (27); "[Johnson] found it relatively easy to overlook the boy's rebellious behaviour" (26); "the doctor slipped a heavy arm around the boy and lumbered his way to a tavern"; "he worried about Francis' frail nature and his susceptibility to illness" (28); "he was beside himself with anxiety" (29); "Johnson suffered daily anxiety about the moral and spiritual well-being of Francis" (30), contributes to the impression of a stable father-son relationship that accommodates individual faults on both sides. Phillips takes pains to convey a sense of the circle that Johnson has drawn around Barber, which protects the latter from the threatening societal discourse he would otherwise have been subjected to at an earlier stage. Analogous to

13. Barber "was no great scholar," but "Johnson was proud of his servant's achievements" and "used to write letters of encouragement to Barber" according to Bundock (120), who argues that Johnson's choice of sending Barber to grammar school was highly unusual (especially when considering that Barber, at this point in life, was in his late twenties) and that Johnson may have had a missionary occupation in mind for Barber (124-5). 
Agency, Masculinity and the Race Episteme in Caryl Phillips's Dancing in the Dark and Foreigners

Johnson's protective circle against a hostile world, the sections which convey this more intimate image of Barber are embedded in a narrative that projects two dominant, yet mutually antagonistic, "societal" views of Barber. Both perspectives on Barber regard him as a representative of their respective concept of black men rather than as an individual, and both use him as an example of their respective discursive positions: the "philanthropic" league, represented by the homodiegetic narrator, perceives Barber as "a creature of childish helplessness" (59), yet a "devoted" and "faithful negro servant" whose "occasional exuberance of personality" must be "reasonably anticipate[d] from a member of his race." Subject as he is to unnatural treatment and living in the wrong clime, Barber is not to be held accountable for his actions according to this view. The "others," by contrast, regard him as a "wastrel [...] wont to freely spend the doctor's money" to "improve his own situation" (6-7), as a threat, a representative of a subhuman kind that needs to be controlled and assigned their place. Within the logic of either view, the relationship between Barber and Johnson appears abnormal and is cast either as a dangerous affront against naturalised societal norms or as an extraordinary, yet instructive, "phenomenon." If the quasi-familial relationship between Johnson and Barber is already subject to controversies, Barber's marriage to Betsy, an official act of racial mixing, provides cause for "scandal" (38) on both sides of the antagonistic divide. Whereas it is met with "consternation" (49) and "disgust" (40) by the "others," it also seems to be an uncomfortable subject for the philanthropic narrator who describes Barber's child as "strangely coloured," "disconsolate," an "apparition" with a "fuzzy head," an "urchin" and "dirty-looking" (17). Accordingly, readers are led to suspect that the narrator ultimately shares the opinion that such a "union," of which the child is a "product," might be "aberrant" $(17,40){ }^{14}$

Johnson's efforts at sheltering Barber from the realities created by these discourses are deceptive, and Barber remains unable to stand on his own feet. Betsy Barber protectively characterises her husband as someone who was cheated, consumed with "sadness" and "not $[\ldots]$ comfortable in mind and body" $(44,54)$. Whereas she locates the reasons for his difficulties in his individual psychic disposition and experience, societal opinion places them in a collective disposition which makes Barber either socially or "naturally" unfit for an independent life in England. Seen either as less-than-human or incompatible "Other," the acceptable roles available for black men in seventeenth and eighteenth century England are delimited. Within these limits, Barber is doomed to remain the servant. By assuming the de facto role of a son, then of a white woman's legal husband, and by attempting to lead a self-governed life (first as an apprentice, ${ }^{15}$ then at sea and later as a modest schoolmaster), Barber clearly transgresses the societal radius of action assigned to him and violates what society has come to see as either laws of conduct or laws of nature. Johnson's legacy, which even posthumously subjects Barber to a destructive benevolence ("Coming to Lichfield was a fulfilment of my master's wishes," 58) ultimately contributes to a scheme which deprives Barber - as a black man - of agency.

Barber's own legacy remains difficult to access, and set against such shining contemporary achievers as Olaudah Equiano, Ottobah Cugoano and Ignatius Sancho - ne-

14. Barber's children, in fact, could have passed for white and Barber was regularly tantalized by contemporaries doubting his fatherhood (Bundock 150-1, 207).

15. Black men in Barber's London were denied access to apprenticeship in skilled professions (Bundock 76-7). 
cessary exceptions to the rule - he is bound to appear as a failure once more. Like the politically conscious and active figures in Williams's life, the abolitionist heroes cast a shadow on Barber's. Did he not have all the access he needed to become a brilliant and authentic advocate against slavery himself, or indeed a man of letters in his own right? Barber's marginalised position in historiography and the lack of an account written by himself leave considerable room for the imagination. Phillips's account overtly exposes the difficulties of access to Barber's experience. His narrator in "Dr. Johnson's Watch" is our only, albeit unreliable, vehicle to his Barber, just as the Johnsoniana were Phillips's (and the revisionist historian's) almost only, equally unreliable, vehicle to the historical Barber. ${ }^{16}$ Yet although Phillips refrains from filling the obvious gaps in historiography with a celebratory myth, he does not leave them blank: rather than inventing a neglected hero or master of subversive action, ${ }^{17}$ he conjures up a troubled personality full of doubt vis-à-vis the conflicting expectations in his person and his societal role - a role which he has not chosen himself. In Phillips's account, which is largely dominated by heterocharacterisations, a long, fictional monologue towards the end of the section "Dr. Johnson's Watch" stands out. ${ }^{18}$ In it, rather than defending his alleged place in London's intellectual circles or exposing injustices committed against him, Phillips's Barber reveals his deeply internalised feelings of inadequacy and self-contempt, musing that "to have established for myself the limits of my abilities" would have been more profitable "than having them blurred by kindness, dependence and my own indolence" (58). Phillips's Barber does not cast an attractive figure and his words are hardly appealing in a context (past or present) which privileges narratives of individual achievement above all else. By choosing Barber and presenting him the way he does, Phillips points exactly to the problematic dominance of such narratives. Thus, he does not satisfy the revisionist impetus expected from biographical writing but subverts it in the face of his readers. The readers are left with a desire to empathise with Barber but sense that to do so might make them complicit with the narrator's discourse, which naturalises Barber's victimhood.

Yet, could he have escaped his dependent status? Barber, arguably, has no choice but to succeed in the role assigned him or be doomed to fail. The disapproval that others feel about his relationship to Johnson and his marriage reveals how strongly the conditional framework that provides the soil for individual freedom and achievement is racialised and thus delimited. The narrator, thus, may have a point in claiming that Barber's spirit was deceived by "company with those of a superior rank" which deprived "him of any real understanding of his own true status in the world" (59). His characterisation of such company as "unnatural" (ibid.), however, is part and parcel of a discursive framework which has fixed "status" as a modern means of categorisation and orientation. Barber's aspirations (or rather: Johnson's aspirations on Barber's behalf) beyond the

16. Until the publication of Michael Bundock's biography of Francis Barber in 2015, accounts of Barber largely drew on the Johnson biographies by Boswell and Hawkins. Whereas Phillips casts Hawkins as antagonist, he mentions Boswell only once, in the third person. This suggests that Boswell is not Phillips's narrator, although his biography of Johnson is used as intertext. The narrator may have been loosely inspired by John Holt, a journalist who wrote for the Gentleman's Magazine and sought out Barber. This visit, however, took place in 1793, whereas the journey of Phillips's narrator is dated nearer Barber's death (Bundock 201).

17. Barber regularly handed Boswell materials pertaining to Johnson and denied Hawkins access to them (Reade 66-9). This moment of exercising control on Barber's part is not exploited by Phillips.

18. For a detailed exploration of narration and characterisation in Phillips's Foreigners and The Atlantic Sound see Pirker (178-224). 
Agency, Masculinity and the Race Episteme in Caryl Phillips's Dancing in the Dark and Foreigners

status assigned him as a black male servant could only be entertained on the inside of the protective, yet deceptive and in his case clearly exceptional and eccentric bubble provided by his master. Ironically, both of Barber's acts of running away are escapes into serving functions (in a different household and for the navy) and both are marred by Johnson who has more ambitious plans for his charge. Educated and no longer conforming to the roles available for him, Barber is thus even deprived of a chance to "perform" in the societally sanctioned role of the servant.

\section{The boxer}

Unlike Francis Barber, Randolph Turpin in the mid-twentieth century became a top achiever in a field that had then only begun to accommodate, but increasingly welcomed, black men: boxing. Turpin's moment of triumph was short, however, and raised expectations which he could not fulfill. The rough outline of his life, as reconstructed in Phillips's account "Made in Wales," contains the following information: after the death of their West Indian father, a first-world-war veteran, Randolph Turpin and his two brothers are brought up by their English mother in Leamington Spa in the 1930s. The troubling energies of the three are channelled when their boxing talent is discovered. Pushed to compete and already a British champion at a young age, Turpin is eventually trained up to fight against the famous American world champion Sugar Ray Robinson. His surprise win makes him a hero for the period of sixty-four days, until he loses the rematch in New York due to a lack of discipline and experience. In spite of enormous efforts, he never regains the championship. Ill-used by his promoter, and financially misadvised, Turpin becomes a show wrestler to make ends meet for his family in Leamington Spa. Turpin's private life is equally turbulent: both his first marriage and an affair with a New Yorker end in court due to allegations of violence. Although his second wife and their daughters provide some emotional stability, he eventually commits suicide, overcome by debt and feelings of inadequacy.

Like the applause Williams receives for his performances, the recognition Turpin receives during his period of success becomes vital for his psychological survival and the sole measure of his value. Conversely, their dependence on recognition leads to their psychic deterioration. Unlike Williams, who continues to receive applause as long as he sticks to the rules of the game he has chosen, Turpin's game is over once he stops winning. Turpin is portrayed at length in "Made In Wales," but the instances in which he - "not much at making speeches" (Foreigners 89) - speaks for himself are rare. This makes his long poem "The Comeback Road," written for his manager in the midst of the downward spiral and introduced as expressing "his feelings about the sport that had both made him and was now breaking him" (142), stand out. The lines "If I make the grade, / [...] / We can look at them all / With a laugh and say, // We've done our best / For the game we love [...] So we'll leave this game / Which was hard and cruel / Then [...] / We'll watch the next man, just one more fool" are evidence of Turpin's profound feelings of inadequacy at having played "the fool" himself, and of his desire to "leave this game" in a dignified manner. This desire makes the "comeback" a necessity: "But my patience is good, / And my willpower strong." The manager is cast as "the one for me," "someone to back me" who will "stick / In a real rough sea" (143), but does not prevent his protégé from adding new damaging defeats to his list. Turpin tragically relies on others, who reap the profits but turn their backs once his boxing career is over. 
Others also represent him as long as it suits them, even in private matters: in court cases ensuing from charges of violence against his first wife, his lover and himself (in an attempted suicide), Turpin's solicitors manage to strike deals that enable him to settle matters with payments and reassure the media of "the lad's stability and good nature" (101-2). Thus, even the most severe charges of violence against others and against himself are always "settled" for Turpin in the interest of his boxing career. The protection is not only deceptive, it is also a thin veil beneath which the discursive framework of race surfaces repeatedly. The individual Randolph Turpin is not only measured in terms of his performance in the role assigned to him, i.e. the boxer, but also in terms of his performance of a widespread concept of black masculinity. When Turpin is alluded to as "bestially primitive" (130; also Morton 225), as "jungle beast in human form and dangerous killer" (137), a causal link between his individual violent outbursts and his blackness is inferred and affirmed. Barber, in "Dr. Johnson's Watch," is referred to in similar terms. Two centuries later, these stereotypes may have receded from "polite discourse." They have not, however, disappeared and can be conjured up in a confrontational situation any time, as Phillips's Foreigners suggests. In "Made in Wales," they surface in the courtroom, but also, strikingly, in the very site of Turpin's triumph: the boxing ring. Turpin's black, male body is made to signal "brutishness" in narratives designed to feed fear, contempt or fascination: "The way Turpin leapt on Griffiths, like a bronze tiger devouring a tethered kid" (98, in a boxing press coverage of the Griffiths-Turpin fight in 1946) and "Turpin, shaven-headed, his sleek brown body gleaming, [...] looked like some copper-coloured warrior of the Frontier days..." (108, in the Daily Express coverage of the Finch-Turpin Fight in 1950). Promoters, too, use Turpin's blackness as "exotic capital": Turpin agrees to spar publicly and sell autographs at Grwych castle, Leslie Salts's "showplace of Wales," complete with "rides and attractions for children" (71). And the one profession that welcomes a "relatively fit coloured man" and "household name" after his boxing days are over, the "burlesque of wrestling," does so for familiar reasons:

The bouts were fixed [...] and the fighters divided into [...] heroes and villains, with the coloured wrestlers - who fought under pseudonyms such as "Johnny Kwango" or "Masambula" - little more than novelty ring fodder to be thrown around for the comic entertainment of the masses. (144)

Phillips establishes a causal link between Turpin's "being late, or forgetting about engagements altogether" and "rumours" about his drinking with his "reservations and evident discomfort" at the "charade" (145), but also points out that he had little choice but put up with the humiliating show.

The commemorative culture surrounding Turpin is selective: whereas a statue erected in Warwick in 2001, sports biographies and a documentary film have contributed to building up the iconography of Turpin as one of the nation's "jolly good fellows" based on his legendary win, Phillips's text draws attention to the heavy implications of this myth for the development of an individual who was at a vulnerable age when he became a star overnight, and whose predicament of having to grapple with his ensuing failure to perform significantly outweighs his brief period of triumph. The carefully constructed coherence of this biography's narration is shattered by the postlude, in which the previously heterodiegetic, seemingly "omniscient" narrative voice momentarily gives way to an experiencing "I," and which offers a complement to the deceptively 
definitive public image of Turpin's rise and fall by suggesting a private side of Turpin known only to his children and grandchildren. They are cast as the bearers of the legacy of a "happy, loving father," a generous man who "looked after loads of people" and "didn't make a fuss about it" and who "never hated anyone" (163-5). While the children are not presented as feeling forsaken by their father, it is Turpin himself who experiences being cheated, betrayed and forsaken by many "fatherly" figures. Like Barber's relationship to Johnson, Turpin's relationship to those who offer to manage, promote and market him is characterised by dependence and reliance. Again, the individual's shortcomings are highlighted, but whereas the individual loses the game, the structures of subjection which have contributed to his deterioration - and which have firmly determined the only valid path towards happiness for him, on which he then fails - remain intact over time. The destructive force of these structures is once more highlighted in the final biography of Foreigners.

\section{The tramp}

"Northern Lights" engages with David Oluwale, the first officially registered "case" of a death in custody in Britain, and for a long time the only case in which officers faced charges. Oluwale's story is told in polyphonic vignettes, which form the following sequence of events: the young Nigerian travels to Britain as a stowaway in 1949 and settles in Leeds. Planning to obtain a university degree, he works in the foundries for long hours. Eventually he "disappears." After an extended period of detention in a mental hospital where he is subjected to heavy medication that changes his personality, he returns to Leeds and a new existence as a tramp. In the streets, he falls prey to a vicious scheme of abuse at the hands of two police officers; after a prolonged period of repeated harassment he is brutally killed. The court case surrounding Oluwale's death created some attention in the media for a short time, but when the novelty had worn off, the media interest faded. By contrast, the memory of David Oluwale assumed symbolic and representative significance in the consolidation of a black British community, emerging in reaction to the shared experience of institutional racism. Phillips does not cast Oluwale as representative, but attempts to approach the individual. Dramatically, however, there is no instance of explicit autocharacterisation in "Northern Lights." After Barber's monologue and Turpin's poem, and in light of the polyphonic structure of the part, this absence appears as overdetermined.

Even more than in his other biographies, Phillips includes recorded or (re-)imagined voices of witnesses who have known Oluwale personally. One of them is a race relations activist who first met him on nights out in places without colour bar, where she notices that he is "smartly dressed" and "a great dancer," but "never paired off or chatted up women." He was "[f]ully integrated into the African group," but not "a political type," was "interested in what we were doing, but he didn't take part" (183, 186-7, 224). She also observes that he has "changed" after the hospital experience, that the "bounce" in his step and "the light" in "his eyes" are gone (204), but does not immeditely realise that he sleeps rough, refusing to accept shelter, because he would get in trouble when racially abused. "David wouldn't take any abuse from anybody [...] including the police. They would always tell me that David had failed the 'attitude test", and "he wasn't prepared to be anybody's victim." Placing him in High Royds "they deliberately made David 'slow' when he was never, ever slow before. [...] Like anybody, David could be 
lippy if you insulted him," but most of the time "he was extremely gentle and polite" (207-8). The woman adds that he "used to have such high hopes for his future," but had "to recognise that all of that had gone." The "'new' David didn't want to be pitied. Not by anybody" (208). This assessment of Oluwale is shared by others: a peer from Lagos remembers him as "stubborn," "never a man to back down," refusing "to play second best"; at the steelworks, "David had the same no-nonsense attitude about him, [...] and I worried about him"; he "simply found it impossible to back down and work the system" (258-9). The young police cadet who eventually instigates the investigation into the case remembers Oluwale as someone "who was doing his business," "going about his routine" and who, with "some sort of courage [...] would still choose to go into that same Bridal house"; as "a mild, quiet person" with "dignity" who "must have been really pissed off $[\ldots]$ with what had gone on" (244). The activist quoted above concludes that "some fatalism had begun to creep into David's spirit. He could have [...] been safe and invisible in different parts of the city, but he didn't want to disappear" (218-9). Oluwale's "tragic flaw" that leads to his downfall, then, is his insistence on agency, even if it boiled down to claiming his sleeping spot "in the same Bridal house" (244).

This insistence appears grotesque when set against the forceful subjection Oluwale had to endure. Already in Phillips's previous biographies of black men, their relative or complete voicelessness in, and subjection to, a violently racialised environment is explicitly staged: none of them are graced with entering the title of the narratives devoted to them; the limited access which we and Phillips's biographical narrators have to their experience is overtly exposed; and instances of autocharacterisation indeed decrease from one biography to the next, disappearing entirely in "Northern Lights," where the absence of Oluwale's voice becomes especially noticeable against the multitude of narrative voices and informants engaging with his "case." The court case itself is dramatically staged, and Phillips includes in the group of antagonists not only the actual perpetrators and their defendants, but representatives of the very policing system (including psychiatry) that has sped up Oluwale's downward spiral. They invariably describe Oluwale as "a wild animal, not a human being" (233), "at times [...] completely withdrawn and inaccessible and on other occasions aggressive, noisy, violent, and disturbed" (234), "built like a miniature Mr Universe" and "like a savage animal," "a small, chunky man, filthy in his personal habits," with a "dirty" language, who "would set up a high-pitched screaming noise," "would scream and shout before being spoken to" (235). Regardless of his aspirations he is described as " not quite educationally subnormal' but [...] certainly not 'bright"' (234), "no more than a 'dosser'," who became a "problem" for those who wanted "a clean city" (233-5). The antagonists' descriptions cast him as a less-than-human, violent madman by disposition, thus effectively diminishing the system's part in the developments and denying the very idea of a development altogether. In Phillips's account of the trial, the defence's "characterisation" (also Aspden 212) is summed up prior to the case made by the prosecution, whose description of the officers and the policing system is rendered, underpinning their thesis of the "continued harassment" to which "Oluwale had been subjected [...] since his arrival in England as a teenager" (235). Witnesses' accounts and prison records further characterise the societal philosophy of law and order as random and exaggerated: "28 days" for "Disorderly Conduct," four days for "Wandering Abroad," and "3 Months" for "Wandering Abroad" and "Indecent Exposure" are only a few examples from the 
Agency, Masculinity and the Race Episteme in Caryl Phillips's Dancing in the Dark and Foreigners

long list of featureless charges (239-40). Importantly, the prosecution's characterisation of Oluwale (Aspden 193) is not given by Phillips, who seems intent on highlighting a different agent in Oluwale's demise.

Although the race episteme is evident in the defendant's attitudes it was not, itself, a subject of the investigations - and, as Kester Aspden argues, it was conspicuously absent from the trial (11). In Phillips's narrative, it is the central aspect of Oluwale's troubles, informing the treatment he received from the two officers, in prison and in the hospital. To underpin this, Phillips integrates a statement by a "National Health Doctor, 2002 " - 33 years after Oluwale's death - who is also quoted anonymously in Browne's study on the black experience in mental health institutions:

These days, the typical black admission is young, in his twenties, loud, paranoid, resisting strongly - you need to get him sedated to restrain him, and the doctors don't know what's going on - he's usually brought in by the police, therefore the doctor hasn't got a clue as to his history - and as with men generally they would be more aggressive, you would be more frightened of them and you would put them on more medication. (209; Browne $67)^{19}$

Browne goes on to conclude, "[t]o be young and black, particularly for males, is to be deemed a greater risk and in need of increased surveillance and greater control." Those who "come into contact with the policing agents" are "seen as requiring control as opposed to care, and custody (or physical restraint) as opposed to cure (Browne 67-8). That considerations like these were not part of the case made by the prosecution in 1971, but were increasingly widely known among Britain's black communities is reflected in "Northern Lights," where one voice draws attention to the "high percentage of black people in prisons and mental homes"; another is "angry. At the time of David's death everybody was angry. Here was a black man and you tell me, what was he doing in the river?" The London Black Panthers, spreading their activities north, "kept mentioning David, and they were very aware of him," and graffiti reading "Remember Oluwale" appears on a wall "near where we would all meet" (248, 169-70). The iconography of resistance, importantly, does not allocate David Oluwale's individuality a central position, but his representative function as a black man victimised by institutions and society due to the hardly acknowledged, but smoothly operating, race-episteme.

In the supposedly "post-racial" climate in which both Dancing in the Dark and Foreigners appeared, neither white nor black audiences were comfortable with being reminded of Williams's blackface acts, with Barber's failure to succeed as a free man, with Turpin's suicide and with Oluwale's "fatalism” (218). Phillips's biographies do not alleviate the discomfort but place it before us, forcing us to behold it. The impetus in Phillips's portrayal of the four men's lives in Dancing in the Dark and Foreigners is thus more complicated than a wish to fill gaps or provide a corrective to inadequate representations. The vociferous discussions about Oluwale and the staged absence of his voice self-referentially highlight the deceptiveness of the very idea of bio-graphy, i.e. the practice of writing another's life. Accepting that these four portrayed men are doomed forever to be spoken about and gazed upon is the paradoxical precondition for any engagement with them.

19. Browne's article appeared in 1995. Phillips's quotation may have been taken from a different source, but the reference to the later date may also imply a creative use of the source, highlighting the postmillennial continuity of the process described. 
Secondly, Phillips's almost exclusive focus on the four men's marred lives, their doom, builds up a strong desire to empathise with them, but the narratorial distance he creates effectively disturbs such an attitude in each and every case. "Regarding the pain of others" (Sontag) is only ever fascinating when these others are kept at a safe distance, are not part of the same conversation and not on the same subject-level. Phillips highlights the continuing processes of subjection, in which he as artist/writer, and we as audience/readers are bound to participate. The portrayed individuals remain distant to the readers, to the author and to the narrators engaging with them, be they "dancing in the dark" or "foreign." That few or no insights are given into their frame of mind and that everything they are reported to have said is explicitly mediated stands in diametrical opposition to the notion of the free (male) individual controlling his fate and development - a subject of desire powerfully propagated by Western discourses from the Enlightenment to the present day, and yet one that is invisibly guarded by boundaries of eligibility. Read together, the four biographies not only project the historical continuity of the race-episteme; they also highlight the continuing discrepancy between the unquestioned ideal of individual achievement and the systemic (and epistemic) limitations marring access to the pursuit of this ideal. The portrayed men are all lured into believing that they could become achievers - masters of their fate - but are all disappointed. This is the universal appeal of their stories.

Eva Ulrike PIRKER

Heinrich Heine Universität, Düsseldorf

\section{Works Cited}

Aspden, Kester. Nationality Wog: The Hounding of David Oluwale. London: Jonathan Cape, 2007.

B., J. "Bert Williams." The Soil: A Magazine of Art 1.1 (1916): 19-23.

BIRAT, Kathie. "Artistic Performance and the Crossing of Boundaries in Caryl Phillips's Dancing in the Dark." Commonwealth Essays and Studies 37.1 (2014): 45-55.

Browne, Deryck. "Sectioning: The Black Experience." Mental Health in a Multi-Ethnic Society: A MultiDisciplinary Handbook. Ed. Suman Fernando. London: Routledge, 1995. 62-72.

Butter, Judith. The Psychic Life of Power: Theories in Subjection. Stanford: Stanford UP, 1997.

Bundock, Michael. The Fortunes of Francis Barber: The True Story of the Jamaican Slave Who Became Samuel Johnson's Heir. New Haven: Yale UP, 2015.

ChUde-SokeI, Louis: The Last "Darky": Bert Williams, Black-on-Black Minstrelsy, and the African Diaspora. Durham, NC: Duke UP, 2005.

Debrunner, Hans Werner. Presence and Prestige: Africans in Europe. Basel: Basler Afrika Bibliographien, 1979.

FANON, Frantz. The Wretched of the Earth. Trans. Constance Farrington. New York: Grove P, 1963.

FAusET, Jessie Redmon. “The Symbolism of Bert Williams.” The Crisis 24.1 (May 1922): 12-5.

Forbes, Camille F. Introducing Bert Williams: Burnt Cork, Broadway, and the Story of America's First Black. Star. New York: Basic Civitas, 2008.

"Happiness." Oxford English Dictionary. 2nd ed. Oxford: Oxford UP, 1989.

Hollinger, David A. Postethnic America: Beyond Multiculturalism. New York: Basic Books, 1995.

Krasner, David. A Beautiful Pageant: African American Theatre, Drama, and Performance in the Harlem Renaissance, 1910-1927. New York: Palgrave Macmillan, 2002.

LEWIs, Lloyd. "Life with Uncle Eggs." It Takes All Kinds. New York: Harcourt, Brace, 1928. 230-7.

Markus, Hazel Rose, and Paula Moya. "Introduction." Doing Race: 21 Essays for the 21 $1^{\text {st }}$ Century. Ed. Hazel Rose Markus and Paula Moya. New York: Norton, 2010.

Morton, James. Fighters: The Sad Lives and Deaths of Freddie Mills and Randolph Turpin. London: Little, Brown and Company, 2005.

PIRKer, Eva Ulrike. Narrative Projections of a Black British History. New York: Routledge, 2011.

PHILLIPS, Caryl. Foreigners: Three English Lives. London: Harvill Secker, 2007. 
Agency, Masculinity and the Race Episteme in Caryl Phillips's Dancing in the Dark and Foreigners

—. Dancing in the Dark. New York: Vintage, 2006.

Pulttano, Elvira. "Migrant Journeys: A Conversation with Caryl Phillips." Atlantic Studies 6.3 (2009): 371-87.

Reade, Alleyn Lyell. Francis Barber, the Doctor's Negro Servant. [Johnsonian Gleanings, Part II]. 1912. New York: Octagon, 1968.

SontAG, Susan. Regarding the Pain of Others. New York: Farrar, Straus and Giroux, 2003.

SotiRopoulos, Karen. Staging Race: Black Performers in Turn-of-the Century America. Cambridge: Harvard UP, 2006.

Williams, Bert. "The Comic Side of Trouble.” The American Magazine (January 1918): 33-5, 58-61. 